University of Montana

ScholarWorks at University of Montana

\title{
Climate, Hydrologic Disturbance, and Succession: Drivers of Floodplain Pattern
}

Diane C. Whited

Mark S. Lorang

Mary J. Harner

F. Richard Hauer

University of Montana - Missoula, ric.hauer@umontana.edu

John S. Kimball

See next page for additional authors

Follow this and additional works at: https://scholarworks.umt.edu/biosci_pubs

Part of the Biology Commons

Let us know how access to this document benefits you.

\section{Recommended Citation}

Whited, Diane C.; Lorang, Mark S.; Harner, Mary J.; Hauer, F. Richard; Kimball, John S.; and Stanford, Jack Arthur, "Climate, Hydrologic Disturbance, and Succession: Drivers of Floodplain Pattern" (2007). Biological Sciences Faculty Publications. 55.

https://scholarworks.umt.edu/biosci_pubs/55

This Article is brought to you for free and open access by the Biological Sciences at ScholarWorks at University of Montana. It has been accepted for inclusion in Biological Sciences Faculty Publications by an authorized administrator of ScholarWorks at University of Montana. For more information, please contact scholarworks@mso.umt.edu. 
Authors

Diane C. Whited, Mark S. Lorang, Mary J. Harner, F. Richard Hauer, John S. Kimball, and Jack Arthur Stanford 


\title{
CLIMATE, HYDROLOGIC DISTURBANCE, AND SUCCESSION: DRIVERS OF FLOODPLAIN PATTERN
}

\author{
Diane C. Whited, ${ }^{1,3}$ Mark S. Lorang, ${ }^{1}$ Mary J. Harner, ${ }^{2}$ F. Richard Hauer, ${ }^{1}$ \\ John S. Kimball, ${ }^{1}$ and Jack A. Stanford ${ }^{1}$ \\ ${ }^{1}$ Flathead Lake Biological Station, Division of Biological Sciences, The University of Montana, 311 Bio Station Lane, \\ Polson, Montana 59860-9659 USA \\ ${ }^{2}$ Department of Biology, The University of New Mexico, Albuquerque, New Mexico 87131 USA
}

\begin{abstract}
Floodplains are among the world's most threatened ecosystems due to the pervasiveness of dams, levee systems, and other modifications to rivers. Few unaltered floodplains remain where we may examine their dynamics over decadal time scales. Our study provides a detailed examination of landscape change over a 60-year period (1945-2004) on the Nyack floodplain of the Middle Fork of the Flathead River, a free-flowing, gravel-bed river in northwest Montana, USA. We used historical aerial photographs and airborne and satellite imagery to delineate habitats (i.e., mature forest, regenerative forest, water, cobble) within the floodplain. We related changes in the distribution and size of these habitats to hydrologic disturbance and regional climate. Results show a relationship between changes in floodplain habitats and annual flood magnitude, as well as between hydrology and the cooling and warming phases of the Pacific Decadal Oscillation (PDO). Large magnitude floods and greater frequency of moderate floods were associated with the cooling phases of the PDO, resulting in a floodplain environment dominated by extensive restructuring and regeneration of floodplain habitats. Conversely, warming phases of the PDO corresponded with decreases in magnitude, duration, and frequency of critical flows, creating a floodplain environment dominated by late successional vegetation and low levels of physical restructuring. Over the 60-year time series, habitat change was widespread throughout the floodplain, though the relative abundances of the habitats did not change greatly. We conclude that the long- and short-term interactions of climate, floods, and plant succession produce a shifting habitat mosaic that is a fundamental attribute of natural floodplain ecosystems.
\end{abstract}

Key words: climate; floodplain; hydrologic disturbance; Pacific Decadal Oscillation; PDO; spatial pattern; succession.

\section{INTRODUCTION}

Floodplains are among the most biologically diverse and productive ecosystems worldwide, but their ecological integrity is compromised by regulation of flow by dams, diversions, and revetments (Tockner and Stanford 2002). Situated at interfaces between upland and river channel environments, floodplains provide habitat and refuge for a vast array of aquatic and terrestrial species and are critical for the conservation of regional biodiversity (Stanford et al. 2005). The diversity of aquatic and terrestrial floodplain habitats is controlled and maintained by variations within the hydrologic regime that influence habitat distribution and turnover. This complex biophysical system of natural river systems has been frequently described as the "shifting-mosaic steady state" model (Arscott et al. 2002, Ward et al. 2002, Hohensinner et al. 2005, Latterell et al. 2006) that describes how ecosystems are comprised of habitat patches that oscillate among several developmental

Manuscript received 29 July 2005; revised 31 July 2006; accepted 21 September 2006. Corresponding Editor: A. S. Flecker.

${ }^{3}$ E-mail: diane.whited@umontana.edu stages, thus sustaining equilibrium of habitat types at the larger scale (Bormann and Likens 1979). This shifting habitat mosaic is a fundamental process attribute of river ecosystems (Stanford et al. 2005) that describes how the distribution of riverine habitat patches change spatially over time in response to flooding, avulsion, cut and fill alluviation, entrainment of large wood, and the recruitment and regeneration of vegetation (Ward et al. 2002, Stanford et al. 2005).

In fluvial systems, flooding structures the physical environment and maintains high levels of habitat heterogeneity and biological diversity across space and time (Bayley 1995, Tockner and Stanford 2002, Junk 2005, Stanford et al. 2005). Flooding continually reworks and reshapes the physical floodplain structure. The varying magnitude, frequency, and duration of these events determine the rate and spatial extent of change across a floodplain over time. Floods of high power and low frequency of occurrence $(\sim 100$-year events) produce major geomorphic changes by channel avulsion and cut and fill alluviation (Hauer and Lorang 2004). Flows of low to moderate power and relatively frequent, and therefore predictable, occurrence $(\sim 1-5$ year return) scour portions of the floodplain, creating the parafluvial 
zone (Fisher et al. 1998), where early successional processes occur. These flood pulses (sensu Tockner et al. 2000) may stimulate seed germination and/or vegetative reproduction of riparian vegetation (Mahoney and Rood 1998) and directly or indirectly influence activity of organisms that use the aquatic-terrestrial transition zone (Junk 2005). Indeed, the entire natural range of discharges is required to maintain ecological function in streams and rivers (Stanford et al. 1996, Poff et al. 1997, Doyle et al 2005). Over time, variation in discharge in large measure determines the composition of floodplain habitats and the dynamics of lotic communities (Power et al. 1988, Resh et al. 1988, Stanford et al. 1996, 2005).

Variations in disturbance regimes are ultimately related to climate. Changes in climate directly impact disturbance regimes (e.g., fire, floods, droughts), indirectly affect landscape composition (Graham et al. 1990), and influence the distribution and abundance of plants and animals (Parmesan and Yohe 2003, Root et al. 2003). Relatively small changes in climate have been shown to significantly alter fire regimes in northwestern Minnesota (Clark 1988, 1990). Using tree-ring data, Clark (1990) showed how fire disturbance was more frequent ( $\sim 8.6$-year return interval) during warm, dry periods of the 15th and 16th centuries and less frequent ( 13.2-year return interval) during relatively cool, wet periods such as the Little Ice Age (1640-1840). Similarly, in the southwestern United States, Molles and Dahm (1990) demonstrated how small temporal scale climate cycles such as the El Niño-Southern Oscillation (ENSO) increase spring runoff and river flow in El Niño years and decrease flows during La Niña years. Likewise, the predictability and frequency of wildfires has been linked to ENSO within the southwestern United States (Swetnam and Betancourt 1990). In addition, interdecadal cycles such as the Pacific Decadal Oscillation (PDO) have been linked to runoff (Dettinger et al. 2000) and snowpack fluctuations (Selkowitz et al. 2002), as well as fluctuations in salmon (Hare et al. 1999) and halibut populations (Hollowed et al. 1998).

Specifically, the PDO has been closely associated with widespread climate variations in the Pacific Basin and North America (Mantua and Hare 2002). In northwest Montana and the larger Pacific Northwest region, the warming phase of the PDO is characterized by lower than average precipitation and warmer than average air temperatures. Similarly, the cooling phase of the PDO is typified by relatively high precipitation and cooler air temperatures (Mantua and Hare 2002). These cooling and warming phases generally oscillate within 20 - to $30-$ year cycles. In the last century, two cooling phases (1900-1924, 1947-1976) and two warming phases (19251946 and 1977-1997) occurred (Hare and Mantua 2000; data available online). ${ }^{4}$

${ }^{4}\langle$ http://www.jisao.washington.edu/pdo/〉
The objective of this study was to examine the configuration and composition of floodplain habitats and their spatial and temporal distribution as influenced by river flows and regional climate at the Nyack floodplain of the Middle Fork Flathead River in northwestern Montana. We used a 60-year record of time-series aerial photographs and digital multi- and hyperspectral airborne and satellite remote sensing imagery coupled with hydrologic and climatic data to investigate how variations in climate affect flood disturbance regimes and subsequent composition of floodplain habitats (i.e., mature forest, regenerative forest, cobble, water). Within the context of this objective we addressed the following questions. (1) How does the distribution and abundance of floodplain habitats change through time? (2) How do these changes relate to river discharge and regional climate?

\section{Methods \\ Study area}

The Nyack floodplain (henceforth referred to as Nyack) is located in northwestern Montana (48 $27^{\prime} 30^{\prime \prime}$ $\mathrm{N}, 113^{\circ} 50^{\prime} \mathrm{W}$ ), on the Middle Fork of the Flathead River, a fifth-order, free-flowing river (catchment area $2300 \mathrm{~km}^{2}$; Fig. 1). Most of the Middle Fork drainage basin is pristine, with headwaters in the Bob Marshall and the Great Bear Wilderness Areas, and the river forms a portion of the southern boundary of Glacier National Park. The Nyack occurs within a glaciated valley between the Livingston and Flathead Ranges, which are part of the regional Lewis overthrust and belt series. Bedrock canyons, both upstream and downstream of the Nyack, form geomorphic knick points constraining flow and channel mobility. Small areas along the western portion of the floodplain have been altered by construction and maintenance of a railroad and highway. The floodplain was homesteaded about 100 years ago and gradual clearing of floodplain forest for wood and pasture has occurred but is limited to the highest- elevation, less flood-prone areas (Fig. 1).

The Nyack floodplain is approximately $2 \mathrm{~km}$ wide and $10 \mathrm{~km}$ in length and is composed of active and abandoned channels, spring brooks, ponds, and stands of regenerating and mature riparian vegetation. Actively scoured areas (parafluvial zone) of the floodplain consist of gravel bars with shallow ponds, large woody debris, and vegetation patches of young cottonwood (Populus balsamifera), willow (Salix spp.), and herbaceous vegetation. Seasonally inundated floodplain benches (active orthofluvial zone; sensu Stanford et al. 2005) consist of mature cottonwood, alder (Alnus incana), and conifers (Picea egelmannii, Abies lasiocarpa, Pseudotsuga menziesii) (Mouw and Alaback 2003).

The Middle Fork of the Flathead River has a spring snowmelt hydrograph, characterized by large seasonal and annual flow variability (Fig. 2); seasonal maximum discharge typically occurs in early June. Mean annual flow is $82 \mathrm{~m}^{3} / \mathrm{s}$, with an average peak annual discharge of 541 


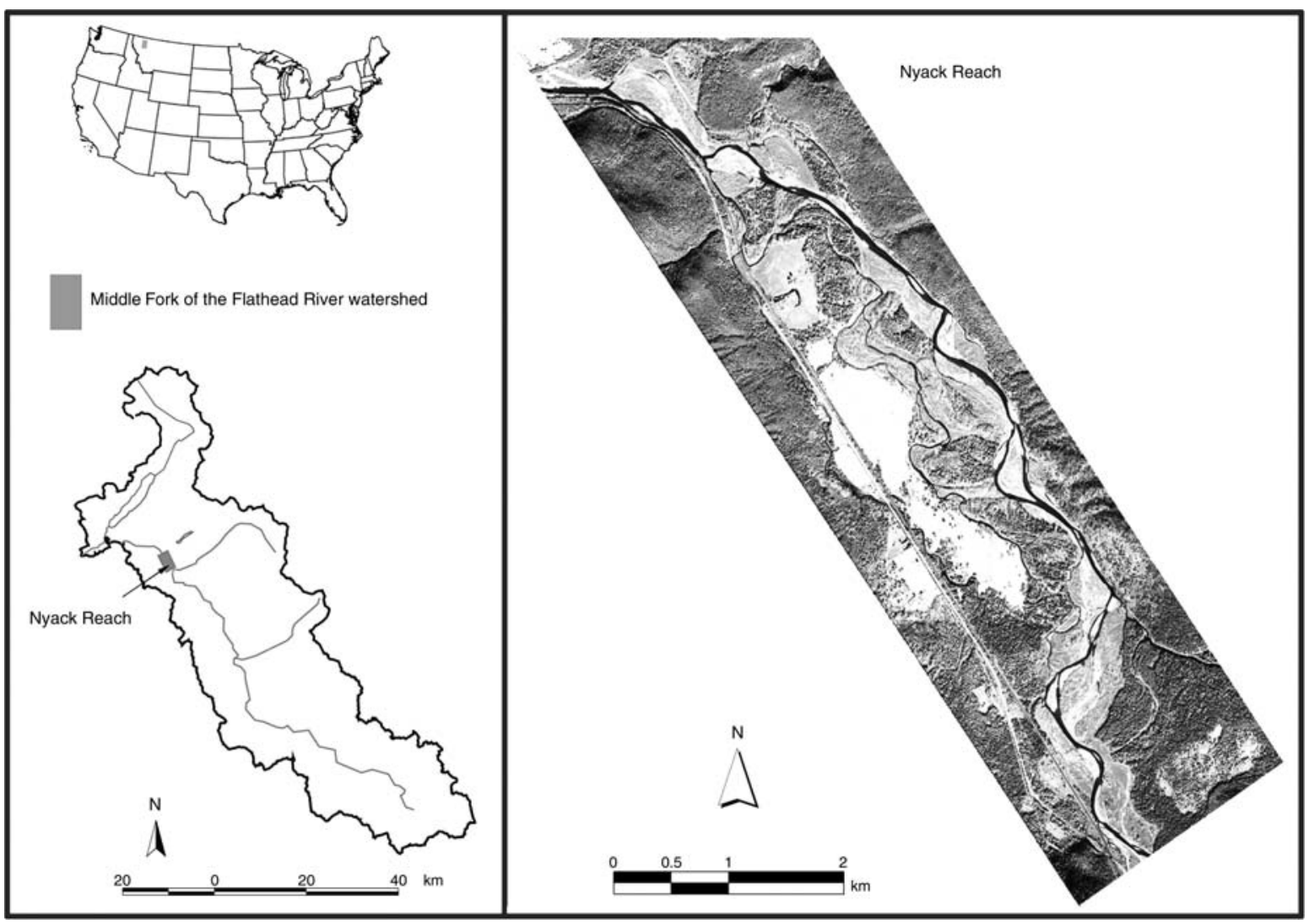

FIG. 1. The Nyack floodplain of the Middle Fork of the Flathead River, located in northwestern Montana, USA. The base layer is a multispectral satellite image taken in October 2004.

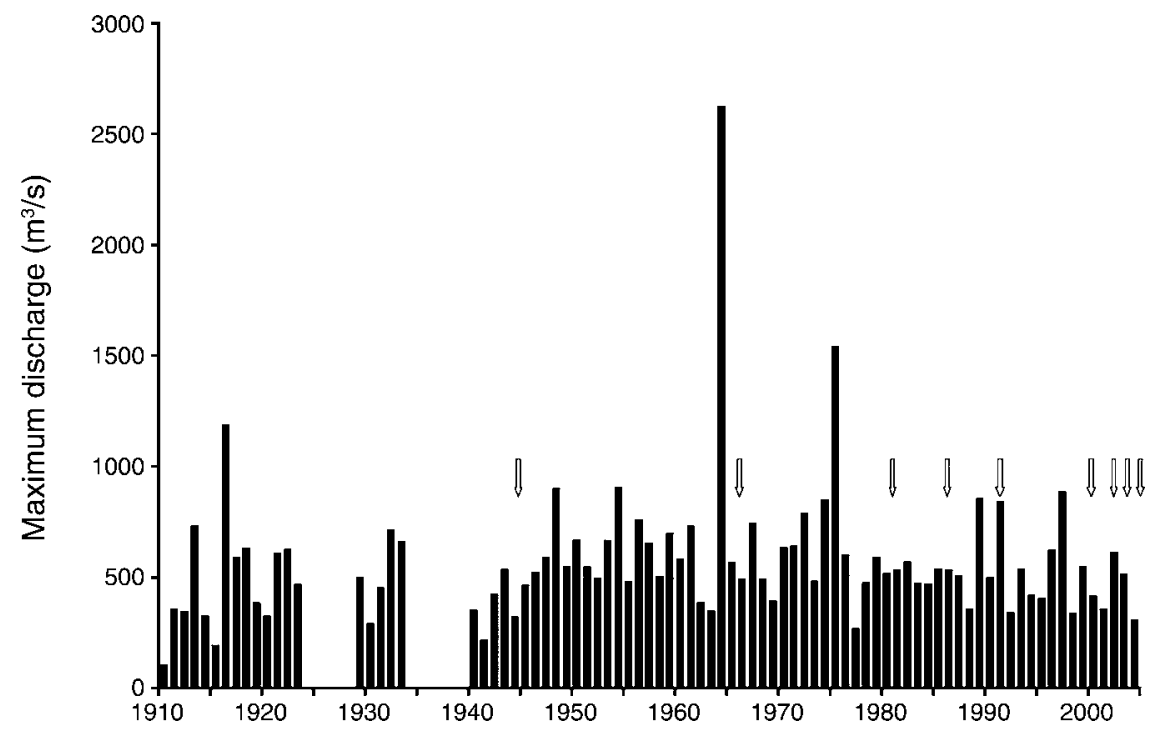

FIG. 2. The maximum annual river discharge on the Middle Fork of the Flathead River between 1910 and 2004. Discharge data are from USGS gages \#12358500 and 12357500. Arrows denote years with historical photographs or airborne or satellite imagery. Zeros for years prior to 1940 denote missing data. 
TABLE 1. Aerial photographs and image data sources used in the analysis.

\begin{tabular}{llc}
\hline \hline Year & \multicolumn{1}{c}{ Image source } & Scale/resolution \\
\hline 1945 & aerial photography & $1: 12000$ \\
1966 & aerial photography & $1: 18000$ \\
1981 & aerial photography & $1: 20000$ \\
1986 & aerial photography & $1: 20000$ \\
1991 & digital ortho photo quad & $1 \mathrm{~m}$ \\
1999 & ADAR imagery & $1 \mathrm{~m}$ \\
2002 & hyperspectral imagery & $1 \mathrm{~m}$ \\
2003 & satellite imagery & $2.4 \mathrm{~m}$ \\
2004 & satellite imagery & $2.4 \mathrm{~m}$ \\
\hline
\end{tabular}

Note: ADAR imagery refers to the Airborne Data and Registration imagery.

$\mathrm{m}^{3} / \mathrm{s}$ and average base flow of $17 \mathrm{~m}^{3} / \mathrm{s}$ (based on 85 -year record from USGS gages \#12358500 and 12357500). Bankfull conditions, determined from field observations, occur at a discharge of approximately $465 \mathrm{~m}^{3} / \mathrm{s}$. The 1-, 5-, and 10-year recurrence intervals for the Nyack are 105, 670 , and $850 \mathrm{~m}^{3} / \mathrm{s}$, respectively (based on $\log$ Pearson type III distribution). The largest recorded flood occurred on 9 June $1964\left(2625 \mathrm{~m}^{3} / \mathrm{s}\right)$, while other large floods in the period of the flow record occurred on 21 June 1916 (1190 $\mathrm{m}^{3} / \mathrm{s}$ ) and 20 June $1975\left(1540 \mathrm{~m}^{3} / \mathrm{s}\right)$ (Fig. 2).

\section{Data sources and processing}

Image data.-We used historical aerial photographs $(1945,1966,1981,1986)$ and airborne and highresolution satellite imagery (1991, 1999, 2002, 2003, 2004; Table 1) to map habitat types across the floodplain over time. River discharge in each image or photograph record was near mean base flow $\left(17 \mathrm{~m}^{3} / \mathrm{s}\right)$ for all years except $1981\left(133 \mathrm{~m}^{3} / \mathrm{s}\right)$ and $1999\left(74 \mathrm{~m}^{3} / \mathrm{s}\right)$, which were still well below bankfull conditions. Aerial photographs were scanned at $600 \mathrm{dpi}$ and georectified to a 1991 digital ortho photo quadrangle (DOQ) with a root mean square (RMS) error of less than $5 \mathrm{~m}$ for all photographs. During image rectification, each photograph was resampled (set pixel size) to a $1-\mathrm{m}$ resolution for consistency across all photographs. The airborne and satellite imagery were acquired from vendors who had previously rectified the images. To confirm spatial accuracy of the airborne and satellite imagery, several locations on each image were compared to the same location on the DOQ. All points were within $5 \mathrm{~m}$, with the majority of locations within $2-3 \mathrm{~m}$ of the DOQ for the entire image series.

Classification of habitats and habitat change.-Five floodplain habitat types were quantified for each the nine sets of images over the period 1945-2004 (see Table 2 for characteristics of each habitat type). The habitats were demarcated using heads-up digitizing (manually drawing polygons around features) in Arc/INFO (version 8.3; ESRI, Redlands, California, USA). A minimum mapping unit (MMU) of $25 \mathrm{~m}^{2}$ was used as a threshold for the smallest patch size. To minimize effects of small spatial errors in the rectification process, such as small polygons along patch edges, we converted the vector coverage (polygons) to raster (pixel) format and resampled the imagery to a coarser spatial resolution $\left(10 \mathrm{~m}^{2}\right)$. We then used these raster coverages for analyses of habitat change. In addition to the five focal habitat types, actively scoured areas (parafluvial zone) were also identified, digitized, and the aerial extents of these zones were calculated for each image.

To characterize Nyack habitat variability over the 60 year image series, we overlaid the raster images and calculated temporal changes in location and aerial extent of each habitat type through the entire image time series (nine image dates with eight time steps). For each individual pixel $\left(10 \mathrm{~m}^{2}\right)$, we recorded the type of habitat change observed. These were classified into four trajectories: stable, recruitment, succession, and restructuring for each transition time step. Recruitment patches indicate areas that progressed from cobble to regenerative forest between two consecutive time points. Succession patches indicate areas that changed from regenerative forest to mature forest over consecutive image dates. Restructuring patches are areas that changed from vegetated to cobble or water during any given time interval. The recruitment and succession trajectories involve growth and development of floodplain forests, whereas the restructuring trajectory involves a re-setting of the floodplain habitats to an initial bare earth state lacking vegetation cover or surface water.

Climate and hydrologic data.-Time series monthly Pacific Decadal Oscillation (PDO) index data were acquired from the University of Washington (data available online). ${ }^{5}$ The PDO index represents the leading principal component of North Pacific $\left(>20^{\circ} \mathrm{N}\right)$ monthly variability of sea surface temperature (SST) and is associated with a general decadal climate cycle that oscillates between relatively persistent warming and cooling phases. PDO warm periods are defined as years when the annual average of the index is greater than 0.5 and PDO cool periods as less than -0.5 . Other years are defined as PDO neutral. In the last century, two cooling phases (1900-1924, 1947-1976) and two warming phases (1925-1946, 1977-1997) have been identified (Hare and Mantua 2000; see footnote 4). PDO data from 1998 through 2004 were excluded from the analysis due to inconsistent patterns of the PDO during this time frame (N. Mantua, personal communication). Daily hydrologic data from 1939-2004 were also obtained from USGS gage site \#12358500 located below the Nyack floodplain on the Middle Fork of the Flathead River. Using the discharge records (1939-1997), maximum, mean, and minimum flows and duration of critical flows were calculated for warming and cooling phases of the PDO.

We designated all discharges capable of transporting the cobble sediment, scouring, and eroding surfaces and banks as critical flows. The duration of critical flows dictates the

\footnotetext{
${ }^{5}\langle$ http://jisao.washington.edu/pdo/PDO.latest $\rangle$
} 
TABLE 2. Characteristics of the five habitat types that were classified on the photographs and images.

\begin{tabular}{ll}
\hline \hline \multicolumn{1}{c}{ Habitat type } & \multicolumn{1}{c}{ Characteristics } \\
\hline Water & All water bodies, including ponds, spring brooks, and side channels \\
Cobble & Areas with no vegetative cover or water \\
Regenerative forest & $\begin{array}{c}\text { Vegetation patches with undefined canopies or small homogenous } \\
\text { patches of young deciduous species, primarily cottonwood and willow } \\
\text { Closed-canopy vegetation usually composed of mixed stands of mature } \\
\text { cottonwoods and conifers } \\
\text { Mature forest }\end{array}$ \\
Pasture and grassland
\end{tabular}

amount of geomorphic work occurring on the floodplain (Costa and O'Connor 1995) and affects vegetation recruitment success and mortality. We used three approaches for estimating thresholds for critical flows on the Nyack. First, a field-based estimate of bankfull discharge $\left(465 \mathrm{~m}^{3} / \mathrm{s}\right.$ and 1.5-year recurrence interval) was identified from field observation of when over-bank flooding and connection with flood channels begins. Wolman and Miller (1960) suggest that bankfull discharge is the effective discharge controlling the development of a floodplain and generally occurs every other year for unregulated rivers. Similarly, Leopold (1992) found that the largest volume of the annual bedload is transported near the bankfull discharge in gravel bar streams. Bankfull (and above) discharge often transports the greatest volume of sediment because much of the river has reached a level of flow competence where sediment transport can be sustained (Lorang and Hauer 2003). The 5- and 10-year recurrence intervals at $670 \mathrm{~m}^{3} / \mathrm{s}$ and $850 \mathrm{~m}^{3} / \mathrm{s}$, respectively, were used as the remaining two critical flow thresholds that represent more intense flows. These flows are more likely to cause parafluvial avulsions and channel changes and provide ideal sites for cottonwood recruitment. Mahoney and Rood (1998) found that successful cottonwood recruitment is generally associated with moderate (5- to 10-year event) flooding. Scott et al. (1997) and Stromberg (1998) concluded that the necessary requirements for cottonwood recruitment and success are met approximately every 10 years, and Lytle and Merrit (2004) found that mature cottonwood populations increased for flood events having approximately 5 - to 15 -year return intervals.

\section{Data analysis}

Evaluating floodplain habitats through time.-We examined the size and distribution of floodplain habitats through time and the success and mortality of cohorts of vegetation. We calculated the percentage of total floodplain comprised of the five different habitat types and of parafluvial for each photograph/image. Second, the type of habitat change (stable, recruitment, succession, and restructuring) was assessed for each of the eight different time steps. Due to the varying time intervals between images, we also normalized the data by evaluating habitat change over three relatively equal time periods (1945-1966, 1966-1986, and 1986-2004).
The percentage of habitat change between images was calculated for each image date and for the three normalized time periods. Individual cohorts (patches of vegetation that established at approximately the same time) were tracked through the time series to evaluate their relative success and persistence by estimating cohort age, area, and elevation relative to the mean water level under base flow conditions. The approximate age of individual cohorts was estimated by identifying the initial colonization patch and tracking the cohort through time. For example, if a cohort first appeared in the 1986 image and also existed in the 1991 and 1999 images, the age of the cohort was calculated to be 15 years in 1999. Using tree-ring data from a previous study on the Nyack (Harner and Stanford 2003), estimates of cohort ages by this method were found to be reasonably accurate. Of the 18 sites where tree-ring data and cohort stands overlapped, the mean difference in age between tree-ring data and estimated cohorts was 3.3 years. In addition, a digital elevation model (DEM) derived in 2002 was used to estimate mean elevations of the remaining cohorts observed in 2004. The DEM was derived from detailed survey data collected in summer and fall of 2002. By overlaying the cohorts on the DEM, mean elevation for each cohort in 2004 was calculated in Arc/INFO.

Evaluating climate, hydrologic conditions, and habitat pattern.-We conducted time-series analyses to assess relationships between hydrologic conditions and yearly PDO averages. A first order autoregressive model (AR1) was fit independently to each time series, and then a bootstrap analysis was carried out to obtain the distribution of correlation coefficient between pairs of time series of interest (e.g., PDO and annual mean flow) under the null hypothesis of independence of the time series. Significance of an observed correlation was assessed by comparing it to the distribution under the null hypothesis.

In order to further assess relationships between hydrologic conditions and the warming and cooling phases of the PDO, we compared the annual duration of the three critical flows calculated from 1939 to 1997 to the PDO phase. Hydrologic data for each year were assigned to either a warming $(n=28)$ or cooling PDO phase $(n=30)$ category. We used a nonparametric 
Kolmogorov-Smirnov test (SPSS 2003) to assess the null hypothesis of no significant difference in duration of critical flows between cooling and warming phases.

We also used a nonparametric rank order test (MannWhitney $U$ ) to evaluate whether PDO phase data were coherent with observed changes in floodplain habitats. Each image and associated habitat classification was assigned to a respective PDO phase (warming or cooling) category and then ranked in ascending order of aerial coverage of key floodplain habitats. We tested the relationship between PDO phase and the ranking of percentage cobble and a combined vegetation (percentages of regenerative forest and mature forest) categories. For example, the percentage aerial coverage of cobble in each image was ranked and tested to determine whether cobble habitats are more abundant during cooling phases of the PDO. Since the post 1997 PDO index data have yet to be categorized relative to cooling or warming phases, we used the annual water year PDO index value to assign post-1997 habitat types to estimated PDO cooling or warming phases for these given years. Using this logic the 1999 and 2002 data were classified under the PDO cooling phase (negative PDO values) and the 2003 and 2004 (positive PDO values) data were classified under the PDO warming phase.

\section{RESULTS}

\section{Change in habitats through time}

Patches of cobble, regenerative forests, mature forests, and the river channel changed locations between 1945 and 2004 (Fig. 3), but the total area covered by each type of habitat did not change greatly (Table 3). Exceptions include an increase in the area of actively scoured parafluvial zone, a reduction in mature forests, and an increase in cobble between 1945 and 1966. The series of images also show a decline in regenerative forests between 1986 and 1999 (Table 3). Although discharge varied slightly across the series of images (Fig. 3), the average floodplain area occupied by active channel and other open water surfaces accounted for only 9.0 to $12.3 \%$ of the total classified area (Table 3). Thus the aerial extent of surface water was similar across the image time series and was not a major influence on the relative proportions of other habitat patches.

While the total area occupied by each habitat type did not change greatly, the spatial distribution of habitat patches (cobble and gravel bars, regenerative forests, and mature forests) on the floodplain changed markedly through time (Fig. 3). The river channel shifted position repeatedly between 1945 and 2004 (Fig. 4A), contributing to widespread change in the location of successional habitats throughout the entire floodplain (Fig. 4B). Over $70 \%$ of the total floodplain area changed habitats at least once, and approximately $25 \%$ of the floodplain changed habitats at least four times between 1945 and 2004. In general, we observed no distinct spatial patterns in habitat change; change occurs often and everywhere.
The trajectories of habitat change (stable, restructuring, recruitment, succession) also varied through time. Habitat restructuring peaked between 1945 and 1966, with $35 \%$ of the floodplain habitats being reset to either water or cobble during this time frame due to the occurrence of the flood-of-record (1964), followed by 23\% restructuring from 1966 to 1981. Habitat restructuring showed a general decline from 1981 until 2004, although these data are skewed somewhat by the shorter time interval between image series in more recent years. Therefore, in our examination of the three relatively equal time periods (1945-1966, 1966-1986, and 19862004), we also found a general decrease in habitat restructuring during these intervals. Habitat restructuring peaked at 35\% in the early time frame (1945-1966), and then declined to 19\% (1966-1986) and 17\% (19862004) in the later time frames. Conversely, within these equal time periods, growth of vegetation showed a general increase through time, with recruitment dominating the middle time frame $(9 \%, 23 \%$, and $9 \%$ respectively) and succession dominating in the more recent time frame $(4 \%, 4 \%$, and $12 \%$, respectively).

Tracking of individual cohorts of regenerating vegetation revealed that size and persistence of these patches varied over the record of images (Fig. 5). The average size of a newly colonized stand was 41.5 ha, with the largest stand (93 ha) establishing after the 1964 flood. These cohorts were also the most successful in sustaining themselves over time, with 57 ha (61\%) of the cohort still remaining in 2004 (Fig. 5), while all other cohorts declined to occupy areas of approximately 20 ha. In general, the initial time step showed the largest decrease in cohorts (independent of the number of years of the time step), with an average decrease of $40 \%$ across all cohorts. The largest decrease in cohort area (65\%) occurred between 1945 and 1966. The mean elevation of cohorts that remained in 2004 (Fig. 5) varied from $1.5 \mathrm{~m}$ to $0.8 \mathrm{~m}$ above the elevation of the river at base flow. In general, older cohorts (those established before 1991) occurred at higher elevations (mean of $1.45 \mathrm{~m}$ ) than younger cohorts (mean $0.87 \mathrm{~m}$ ).

\section{Climate and river flow}

The PDO index (Fig. 6A) varied over the last century, oscillating between cooling and warming phases every 20 to 30 years. Similarly, maximum flows (Fig. 6B), minimum flows (Fig. 6C), and duration of critical flows (Fig. 6B), as well as days below baseflow (Fig. 6C), also fluctuated through time. The PDO index showed a strong autocorrelation (0.65), which is consistent with other recently published studies (Overland et al 2006). Autocorrelation was slight for maximum (0.018), mean (0.051), and minimum (0.099) flows, corresponding to a much shorter persistence of departures from the mean than exhibited by the PDO index. Results from the bootstrap simulation showed that the observed correlation between PDO and maximum flow $(-0.261)$ was improbable (probability, $P=0.02$; one-tailed) under the 

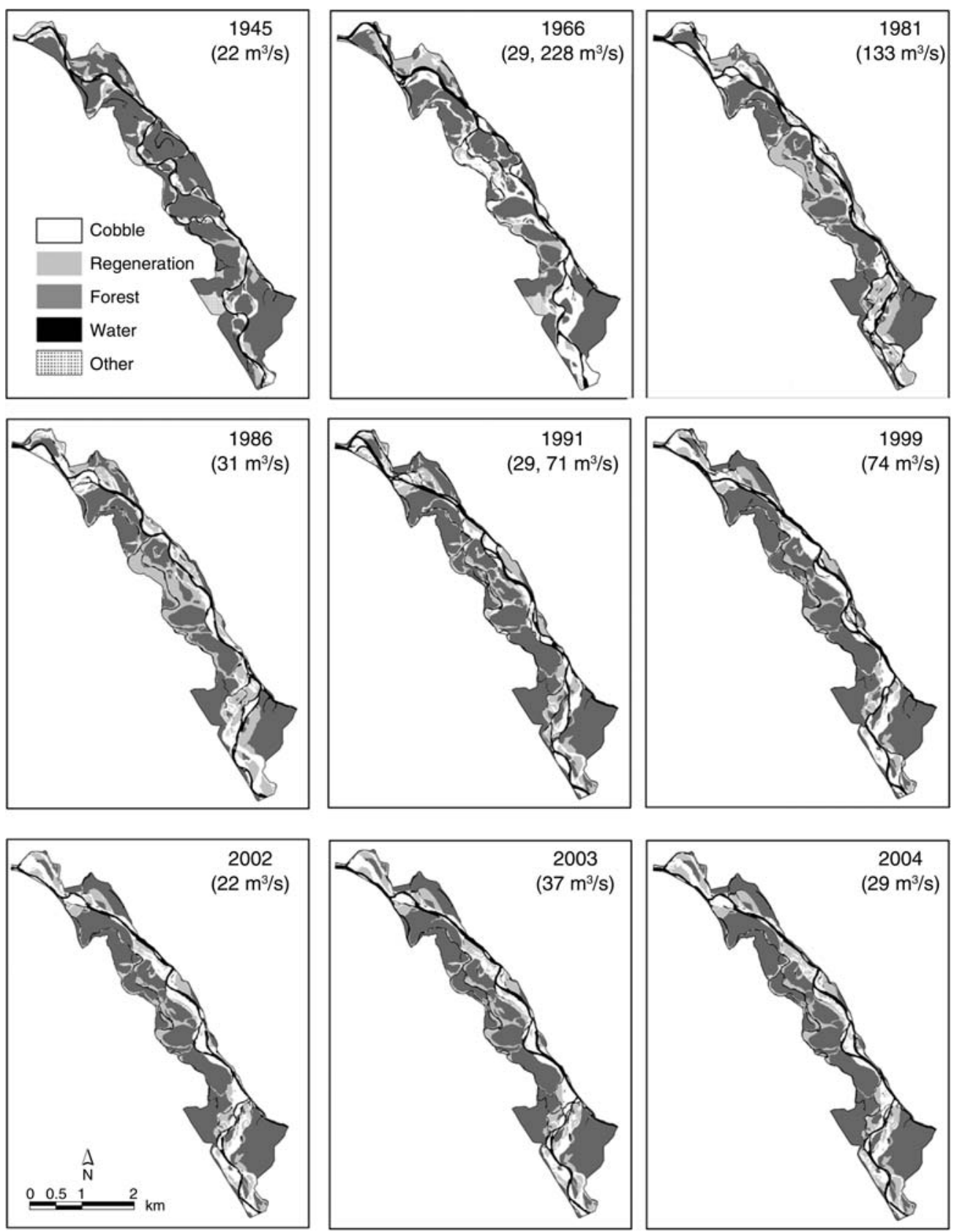

FIG. 3. Time series of the Nyack floodplain from 1945 to 2004. Five habitat types (water, cobble, regenerative forest, mature forest, and other) are displayed along with the river discharge on the day of photo or image acquisition. The composite images for 1966 and 1991 were acquired at multiple times during those years; thus two different discharges are shown.

null hypothesis of independence of time series. Similarly, the observed correlation between PDO and mean flow $(-0.358)$ was improbable $(P<0.01$; one-tailed $)$ under the null hypothesis. However for minimum flow the observed correlation $(-0.079)$ was reasonably probable $(P=0.3)$. Thus, we concluded that the association of the annual PDO index with maximum flow and mean flow aspects of hydrologic conditions were indeed significant. The lack of coherence with minimum flow likely relates to storage of water in the alluvial aquifers that buffer base flow variation in this floodplain river.

Correlations between the PDO and flow data revealed that during the cooling phase, recurrence intervals of critical flows were shorter, the duration of critical flows lasted longer (more than doubled), and maximum and mean flows were significantly higher than during the warming phases (Table 4). Results from the Kolmogorov-Smirnov test show significant differences between the 
TABLE 3. Percentage of the total floodplain area occupied by each of the five habitat types and percentage of the total floodplain area classified as parafluvial (actively scoured) for each year in the time series.

\begin{tabular}{lcccccc}
\hline \hline Year & Cobble (\%) & Regeneration (\%) & Mature forest (\%) & Water (\%) & Other (\%) & Parafluvial (\%) \\
\hline 1945 & 11.3 & 7.9 & 65.5 & 9.8 & 5.4 & 23.7 \\
1966 & 29.1 & 9.7 & 48.0 & 10.6 & 2.6 & 50.9 \\
1981 & 19.5 & 21.3 & 43.6 & 12.3 & 3.3 & 38.0 \\
1986 & 19.3 & 26.4 & 53.3 & 9.4 & 1.3 & 40.9 \\
1991 & 16.7 & 17.2 & 52.1 & 12.2 & 0.9 & 38.6 \\
1999 & 20.8 & 14.0 & 52.1 & 5.0 & 1.6 & 38.6 \\
2002 & 22.6 & 15.3 & 51.6 & 10.9 & 0.8 & 38.6 \\
2003 & 20.0 & 16.5 & 51.1 & 10.7 & 0.8 & 39.0 \\
2004 & 18.1 & 18.8 & 6.5 & 1.2 & 1.9 & 39.0 \\
Mean & 19.7 & 16.3 & & & & 6.9 \\
SD & 4.7 & 5.6 & & & &
\end{tabular}

PDO phases for the number of days above bankfull flow conditions, and the number of days above the $670 \mathrm{~m}^{3} / \mathrm{s}$ (5-year recurrence interval) flow thresholds $(P<0.01)$. No significant differences between PDO phases were observed for minimum flows or days above the 10-year recurrence interval $\left(850 \mathrm{~m}^{3} / \mathrm{s}\right)$. The recurrence interval for field-based bankfull conditions $\left(465 \mathrm{~m}^{3} / \mathrm{s}\right)$ showed little change between PDO cooling and warming phases, averaging approximately 1.4 and 1.6 years, respectively. However, the recurrence interval for floods above 670 $\mathrm{m}^{3} / \mathrm{s}$ (our 5-year recurrence interval threshold) more than doubled during PDO warm phases. Similarly, floods above $850 \mathrm{~m}^{3} / \mathrm{s}$ (the 10 -year recurrence interval threshold) occurred approximately every 6.4 years during PDO cooling phases compared to approximately 12.2 years for warming phases.

Although the pre-1939 data were not included in the time series analyses, the third largest flood on record $\left(1190 \mathrm{~m}^{3} / \mathrm{s}\right)$ occurred in 1916 during the $1900-1924 \mathrm{cool}$ phase of the PDO. However, several days in this time period were below baseflow conditions and others had relatively short durations of critical flows. The mean PDO index value for this period was positive $(0.06)$, while the mean PDO index value from 1947 to 1976 was negative $(-0.61)$.
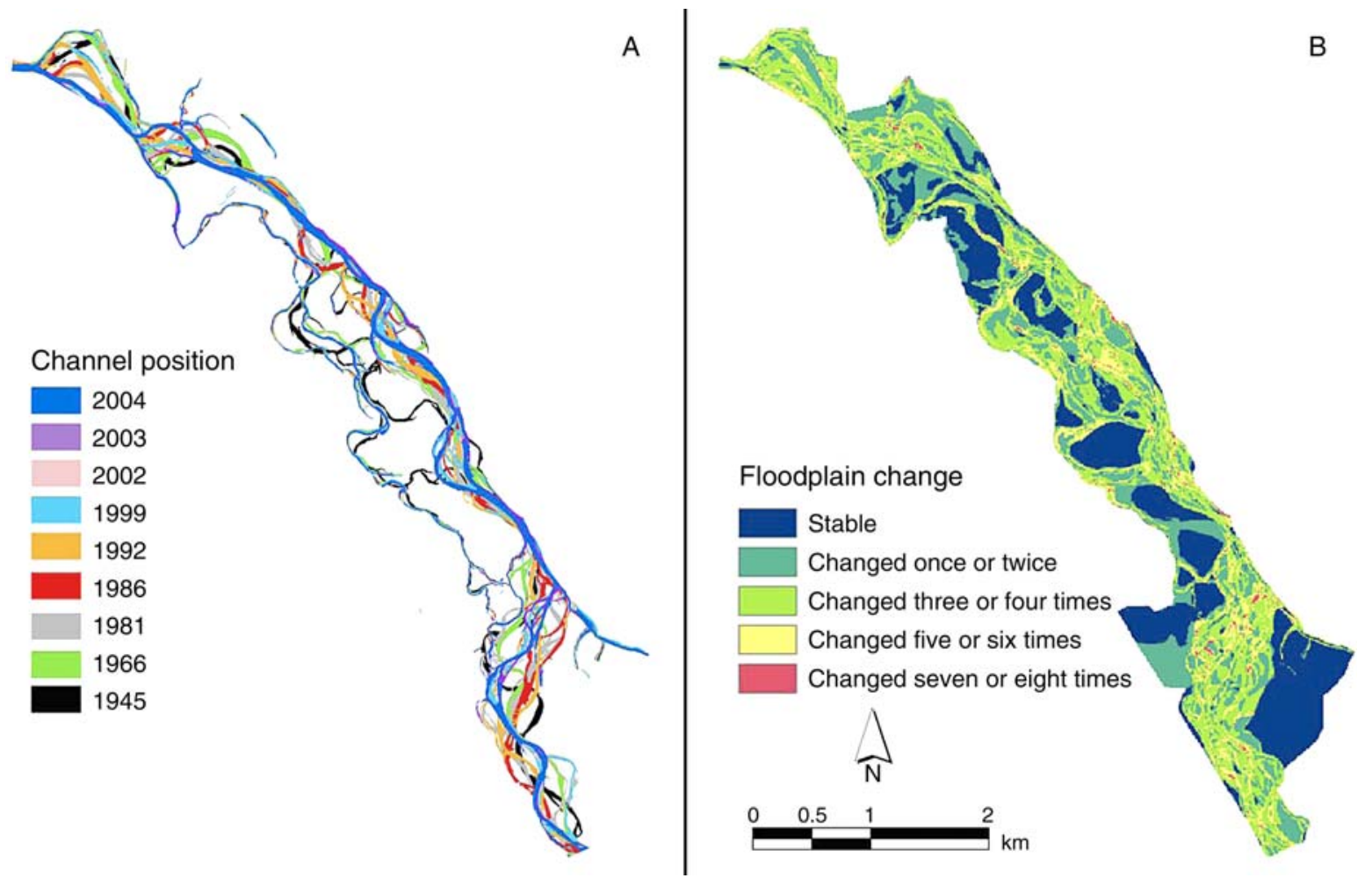

FIG. 4. (A) Location of river channels at nine points in time between 1945 and 2004. (B) Frequency of changes in cover type over a given area (675 ha) of floodplain between 1945 and 2004. Blue regions indicate portions of floodplain that did not change (i.e., remained as mature forest over the entire time series), whereas the green, yellow, and red indicate regions that shifted between different types of habitats (i.e., cobble, regenerating forests, water) between time points. 


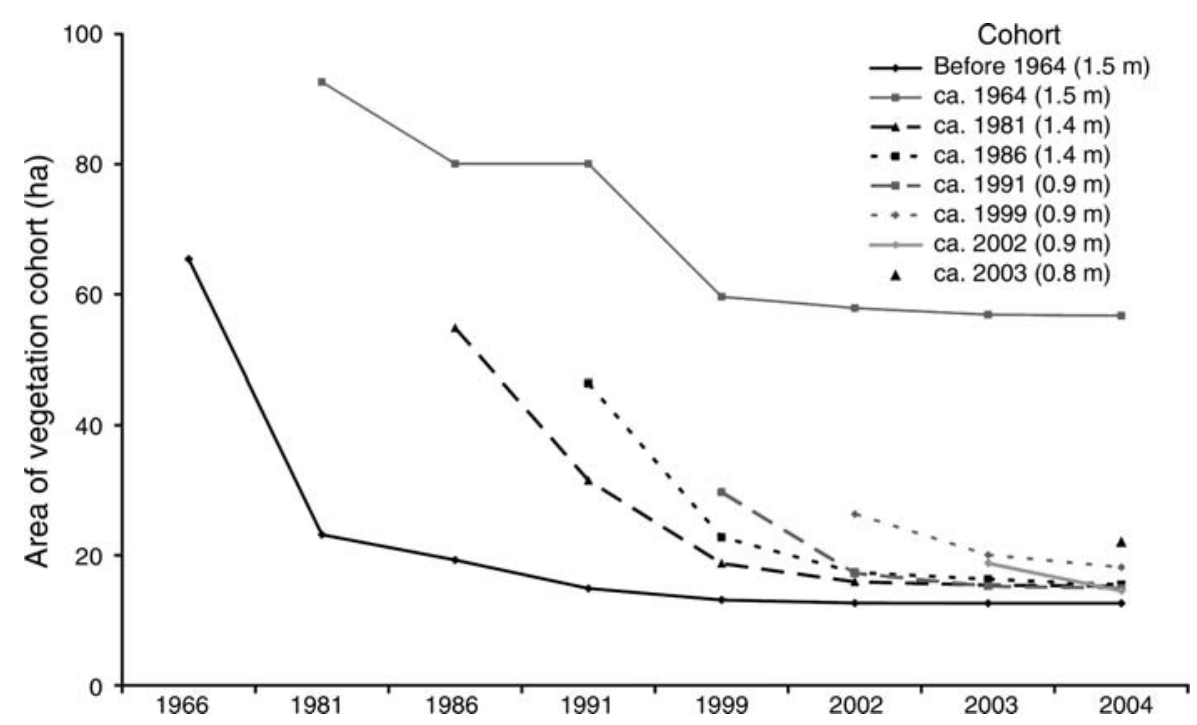

FIG. 5. The area and success of each cohort of vegetation patches over time. The mean elevation of the remaining cohorts observed in 2004 is also reported in the legend.

\section{Climate and habitat pattern}

During the cooling phases of the PDO, the highest proportion of cobble surfaces was observed, with $29 \%$ of the floodplain occupied by cobble in 1966, followed by $22.6 \%$ in 2002 and $20.2 \%$ in 1999 . The average percentage of cobble under PDO cooling phase years was $24.6 \%$ compared to $17.5 \%$ for PDO warming years. The results of the Mann-Whitney $U$ test showed a significant relationship between PDO phase and aerial extent of cobble surface $(P<0.01)$, but no evidence of a significant relationship to the percentage of vegetation cover within the floodplain. However, the average percentage of vegetation cover for PDO warming years was slightly higher $(69.4 \%)$, compared to $63.7 \%$ for PDO cooling years.

\section{DisCUSSION}

Our analysis presents snapshots of the composition, distribution, and development of habitat patches on a floodplain over a 60 -year time period. These habitats change spatially in response to variations in hydrological disturbances, which in turn are related to regional climate. A balance exists between the magnitude and frequency of critical flows, the area that can be colonized by vegetation, and the rate and success of regeneration and development of vegetation; these competing processes produce the floodplain composition observed today. Furthermore, the alternating periods of hydrologic disturbance and successional processes reflects interdecadal cycles of cooling and warming associated with the PDO. Floods of large magnitude occur during cooling phases and produce extensive habitat restructuring. Conversely, less extensive flooding occurs during warming phases, contributing to regeneration and succession of vegetation.

\section{Hydrologic disturbance and successional controls on floodplain pattern}

Our results indicate that hydrologic processes produce predictable patterns of structure on the Nyack floodplain. Three patterns, mature, major disturbance, and moderate disturbance, are evident from 1945 to 2004 (Fig. 7). These patterns are linked to the magnitude, duration, and recurrence intervals of floods and rates of vegetation succession, with changes in floodplain composition corresponding to shifts in the disturbance regime. For example, the largest change in floodplain composition occurred between 1945 and 1966 (Fig. 3). Mature forests of cottonwoods and conifers dominated the floodplain in 1945, but by 1966 a large portion of the floodplain consisted of cobble and young, regenerating forests (Table 3). This shift resulted from extensive reworking of the floodplain during the 1964 flood. Another large flood occurred in 1975, after which the floodplain entered a recovery stage where colonization and regeneration of vegetation flourished under a moderate disturbance regime. Hydrologic conditions during this time were less intense compared to the 1964 flood; only three floods exceeding $670 \mathrm{~m}^{3} / \mathrm{s}$ (5-year recurrence interval) were recorded (Fig. 2). Nonetheless, the floodplain composition changed, especially in the parafluvial, albeit less substantially than during the period between 1964 and 1975. Therefore we call this period a "moderate disturbance" pattern. In general, the forests of the Nyack have matured during the period of record. Given several more decades with only small to moderate floods, the floodplain habitats may come to resemble the composition of the mature forest depicted in the earliest (1945) photo record.

The recurrence intervals of critical flows that cross geomorphic thresholds may define the trajectory (growth vs. restructuring) of floodplain habitats, which 
FIG. 6. (A) The Pacific Decadal Oscillation (PDO) index between 1910 and 2000 (Mantua 2001). Positive values represent a warming phase, and negative values correspond to a cooling phase of the PDO. (B) Maximum river discharge and the duration of critical flows. The $465 \mathrm{~m}^{3} / \mathrm{s}$ threshold represents bankfull discharge estimated from field observations. The $670 \mathrm{~m}^{3} / \mathrm{s}$ threshold represents the five-year recurrence interval. Data points and lines indicate the number of days above critical thresholds (right-hand axis). (C) Minimum river discharge (black lines and solid diamonds) and the number of days each year with flows below the average base flow of $17 \mathrm{~m}^{3} / \mathrm{s}$ (gray bars). (D) The percentage of total floodplain area dominated by cobble, regenerative forest, and mature forest. The large gray shaded section represents a distinct cooling phase of the PDO (1947-1976).
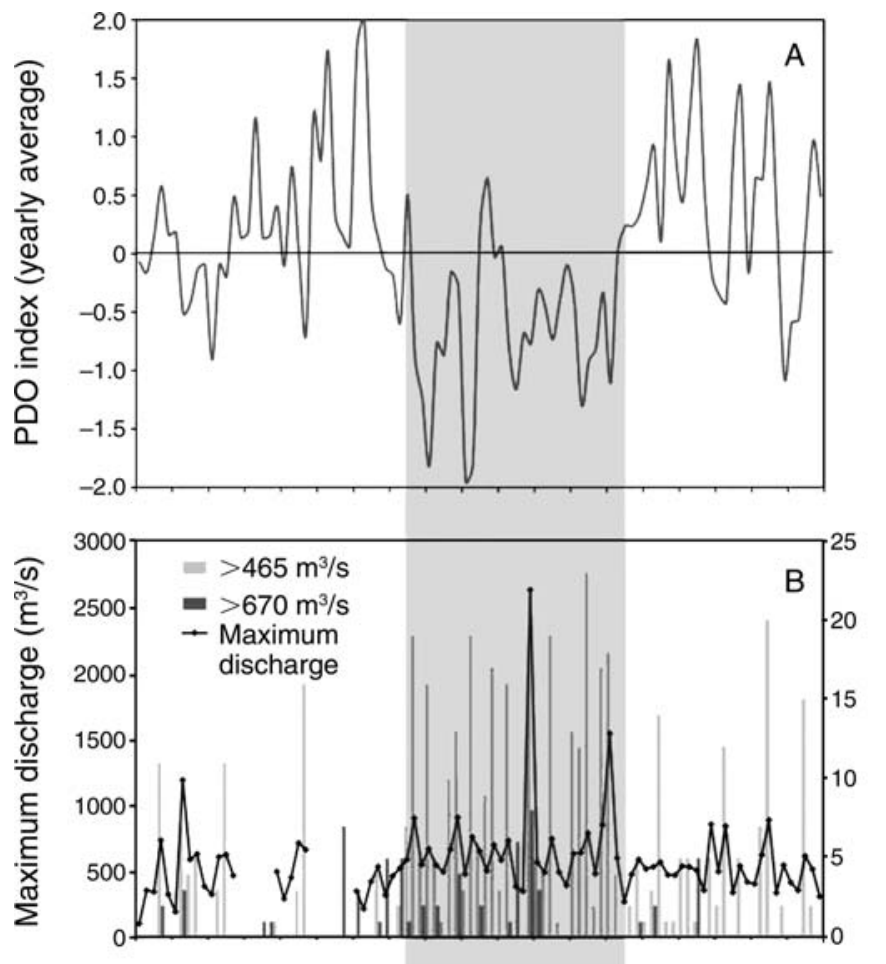

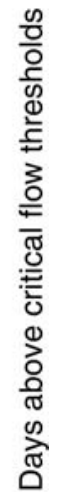
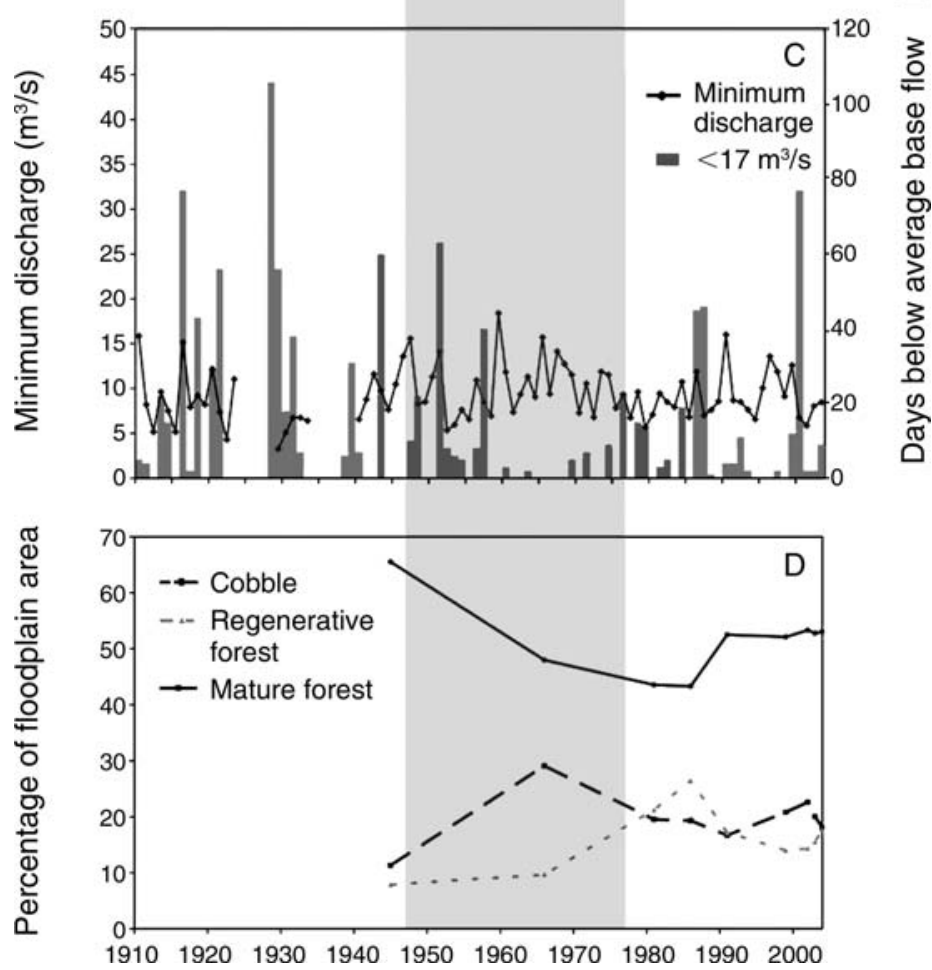

in turn affect the complexity and diversity of the riverine landscape. For example, when the recurrence interval of major landscape forming flows (e.g., 100-year event) begins to closely approximate the duration of the riparian succession from recruitment to mature stands, then the potential exists to create a floodplain mosaic that more closely resembles a mature successional state with a lower level of pattern complexity. This is the pattern observed on the Nyack in 1945 when mature forests dominated the floodplain landscape. Alternatively, when the recurrence interval for major geomorphic critical flows is less than the time needed for forests 
TABLE 4. Summary (yearly averages) of hydrologic conditions during the most recent warming and cooling phases of the PDO.

\begin{tabular}{lcc}
\hline \hline \multicolumn{1}{c}{ Variable } & $\begin{array}{c}\text { Cooling phase } \\
(1947-1976)\end{array}$ & $\begin{array}{c}\text { Warming phase } \\
(1939-1946,1977-1997)\end{array}$ \\
\hline Maximum flow $\left(\mathrm{m}^{3} / \mathrm{s}\right)$ & 664.7 & 495.7 \\
Mean flow $\left(\mathrm{m}^{3} / \mathrm{s}\right)$ & 86.5 & 74.6 \\
Minimum flow $\left(\mathrm{m}^{3} / \mathrm{s}\right)$ & 9.8 & 9.1 \\
Days above $465 \mathrm{~m}^{3} / \mathrm{s}^{* *}$ & 8.2 & 3.3 \\
Days above $670 \mathrm{~m}^{3} / \mathrm{s}^{* *}$ & 3.7 & 0.6 \\
Days above $850 \mathrm{~m}^{3} / \mathrm{s}$ & 0.3 & 0.1 \\
Days below $10 \mathrm{~m}^{3} / \mathrm{s}$ & 7.8 & 10.4 \\
Critical flow thresholds & & \\
$465 \mathrm{~m}^{3} / \mathrm{s}$ recurrence interval $(\mathrm{yr})$ & 1.2 & 7.6 \\
$670 \mathrm{~m}^{3} / \mathrm{s}$ recurrence interval $(\mathrm{yr})$ & 2.9 & 12.2 \\
$850 \mathrm{~m}^{3} / \mathrm{s}$ recurrence interval $(\mathrm{yr})$ & 6.4 & \\
\hline
\end{tabular}

Notes: The days above a given threshold (e.g., $465 \mathrm{~m}^{3} / \mathrm{s}$ ) represent the yearly average of the total days above a given threshold (not continuous days above a threshold) for either the cooling or warming phase. The critical flow thresholds illustrate how the recurrence intervals are adjusted for the cooling and warming phases. Significant results from the Kolmogorov-Smirnov test are denoted. ** $P<0.01$.

to undergo maturation, then the mosaic of habitats resembles early stages of plant succession. This latter pattern is typical of highly braided rivers with a highfrequency disturbance regime, such as the Tagliamento River in Italy (Kollmann et al. 1999, Arscott et al. 2002). Moderate flood recurrence intervals (e.g., 10-year events) or a combination of high, moderate, and low disturbances over decadal time periods appear to maintain a state of maximum complexity of habitats within a floodplain (Ward et al. 1999).

The Nyack floodplain is in a state of constant flux; fluvial disturbance balanced by the rate of recovery and success of vegetation recruitment create a shifting habitat mosaic that maximizes biodiversity and drives the life cycles of biota in floodplain ecosystems (Stanford et al. 2005). Over 500 species of aquatic invertebrates, a majority of native fishes in the Flathead
Basin-Glacier National Park area, and $68 \%$ of the regional vascular flora (Mouw and Alaback 2003) have been documented (Stanford et al. 2005) on the Nyack floodplain. Our study shows that over a 60-year record, changes in the locations of floodplain habitats (water, cobble, regenerative forests, and mature forests) were widespread, with $70 \%$ of the Nyack floodplain undergoing a change in habitat composition at least once. However, the total area of habitats on the floodplain did not change greatly through time (Table 3 ). At any given floodplain location, most habitat types turned over at least every one or two decades, but the total area occupied by each habitat within the floodplain remained fairly uniform. The landscape-level spatial and temporal patterns of habitat change and composition observed on the Nyack floodplain are consistent with findings by Arscott et al. (2002) and van der Nat et al. (2003) along

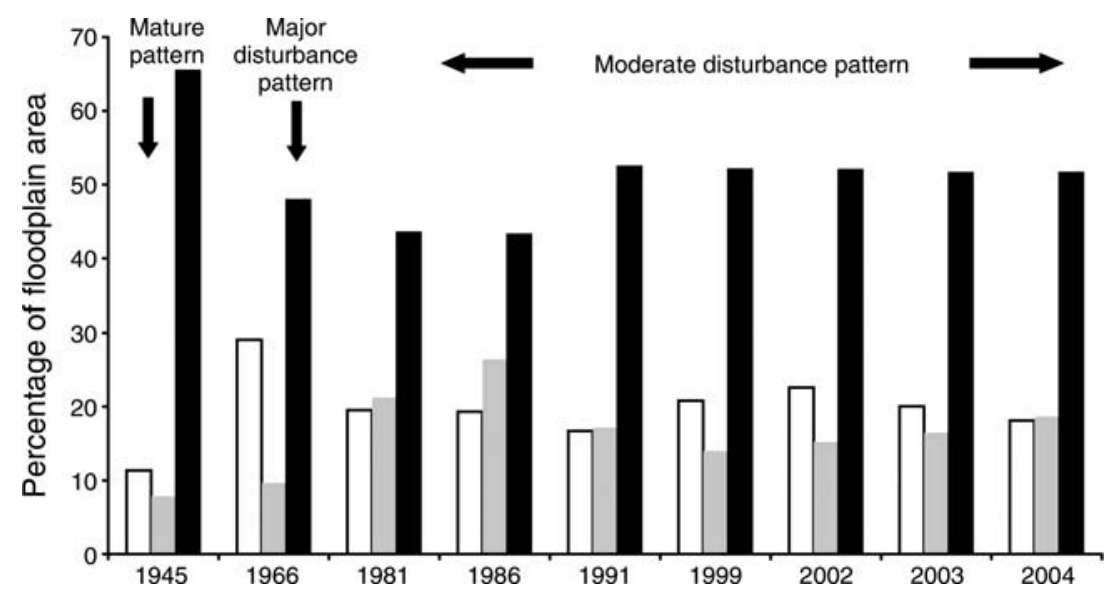

FIG. 7. Percentage of total area of floodplain dominated by cobble (white bars), regenerative forests (gray bars), and mature forests (black bars) between 1945 and 2004. The mature pattern (1945) is typified by a floodplain composition dominated by mature forest; the major disturbance pattern (1966) is characterized by a large shift in floodplain composition, primarily a shift from forest to cobble; and the moderate disturbance pattern (1981-2004) is characterized by minimal changes in the floodplain composition. 
the Tagliamento River in northeast Italy, whose work also supports the shifting mosaic steady state model (Bormann and Likens 1979). Arscott et al. (2002) and van der Nat et al. (2003) demonstrated that relative proportions of a given type of aquatic habitat remain constant through time, despite frequent changes in location of habitats within the landscape, though they worked at scales of 1-2.5 years, whereas our study supports the model over several decades.

\section{Development of riparian forest}

The distribution and age of cottonwood forests reflect a legacy of hydrologic conditions, from large scouring floods that create expansive areas for recruitment, to extended periods of moderate to low disturbance that promote succession. The development of cottonwood forests requires creation of suitable sites (bare and moist), the availability of seeds or deposited wood (Karrenberg et al. 2002), adequate soil moisture (Mahoney and Rood 1998), and suitable flows following colonization to allow a given cohort to survive (Lytle and Merrit 2004). On the Nyack, we found that following the two largest floods on record (1964 and 1975), recruitment and succession of vegetation increased over time. This period was typified by low magnitude and short duration of critical flows, but still maintained sufficient flows through the growing season to sustain vegetation (Fig. 6B, C).

Large, infrequent floods scour areas at various elevations and spatial positions throughout the floodplain, thus providing a variety of conditions for recruitment and succession of riparian species. Our results indicate that the largest and most successful cohorts of cottonwoods were established following the 1964 and 1975 floods and are all situated on elevated deposits (Fig. 5). Scott et al (1997) also found that cottonwood establishment and survival along the Missouri River was most successful following infrequent, large floods capable of scouring elevated flood deposits. Similarly, the remainder of the 1986 cohort is also found on elevated deposits (Fig. 5). It appears the 1964 and 1975 floods created such a large expanse of suitable surfaces that widespread colonization and establishment of riparian vegetation was still occurring several years following these events. While most colonization likely occurs during the initial flood year (Stromberg 1998, Bendix and Hupp 2000), additional colonization can occur following a large flood event if environmental conditions remain suitable for cottonwood recruitment (Merigliano 1998, Rood et al. 1998). Thus, the Nyack floods of 1964 and 1975 appear to have facilitated the establishment of relatively large patches of forests throughout the floodplain that persist today as key features because they have been largely unaffected by subsequent floods and scouring flows.

As the Nyack floodplain continued to evolve following the large floods, the availability and quality of colonization sites were observed to decrease over time and were generally restricted to parafluvial sites. After the colonization and establishment of the cohorts on 1966, 1981 , and 1986 , only $17 \%$ of the floodplain was available for colonization (compared to $29 \%$ in 1966); thus from 1991 on only small cohorts have been established and these are restricted to lower elevations in the parafluvial (Fig. 5). These cohorts are probably less likely to reach maturity due to their higher susceptibility to inundation and scouring on an annual basis (Scott et al. 1997). On the Nyack, the temporal asynchrony of disturbance events coupled with the variation in the extent and spatial location of these disturbances produces a floodplain mosaic characterized by several stages of succession that occupy various locations and environmental conditions on the floodplain.

\section{Implications for a changing climate}

Regional climate cycles inferred by the PDO index have been shown to influence the state of natural resources in the Pacific Northwest (Selkowitz et al. 2002). In Glacier National Park, which borders the Nyack floodplain, winter snowpack fluctuations (Selkowitz et al. 2002) and winter glacial ice accumulations and summer ablation (Pederson et al. 2004) correspond strongly with interdecadal patterns of the PDO. Similarly, our results show that the cooling phase of the PDO from 1947 to 1976 produced flood flows that caused extensive habitat restructuring, resulting in a substantial decrease in mature forest habitats and a significant increase in the aerial extent of cobble (exposed surfaces). The most recent PDO warming phase (1977-1997) was characterized by low restructuring and coincided with large increases in riparian forest regeneration and succession. Although, no relationship between vegetation cover and changes in the PDO phases were observed, the successful recruitment and succession of vegetation spans several years and is not observed as an immediate response to changes in climate and hydrologic conditions. Unlike the creation of cobble surfaces, which represents a relatively abrupt response to changes in hydrologic and climatic patterns, the development of riparian vegetation is a time-lagged response due to the relatively slow processes of cottonwood recruitment, regeneration, and succession. The current habitat composition of the Nyack floodplain reflects a PDO warm phase successional trajectory, with over $70 \%$ of the floodplain consisting of regenerative and mature forest. If current climatic conditions prevail, the magnitude and frequency of large floods will most likely remain low, allowing a general progression toward predominantly mature riparian forest habitat.

The relatively strong relationships between PDO, hydrologic disturbances, and floodplain composition characterize this floodplain (Fig. 6) and allow use of the PDO index to extrapolate the disturbance history prior to the recent hydrologic record and to speculate on how the composition of Nyack may have looked prior to 1945. Although our hydrologic data extend back to 
1910, the record is incomplete until 1939 when continuous data collection began. The floodplain composition of 1945 was dominated by mature forest, thus we suspect the period preceding 1945 was characterized by a general lack of large flood events. Indeed, the period between 1924 and 1945 is classified as a warming phase in the PDO and should promote riparian regeneration and succession processes. However, this short time frame does not entirely account for the mature forest pattern recorded in 1945. The period between 1920 and 1924 is classified as a PDO cooling phase, but does not appear to be as strong as the most recent cooling phase (1947-1976). From 1900 to 1924 the average PDO index is actually positive $(0.06)$, suggesting this phase probably did not produce many large floods or long durations of critical flows and was probably more similar to conditions between 1925 and 1945 even though the third largest flood on record occurred in 1916. This flood was less than half of the intensity of the 1964 event and probably reworked mainly parafluvial areas, thus resetting succession in relatively small areas throughout the floodplain. Thus the PDO index and sparse hydrologic data record prior to 1945 imply that disturbance events during this period were relatively minor in magnitude, duration and frequency, allowing forest regeneration and succession to dominate, and resulting in the predominantly "mature pattern" observed in the 1945 floodplain image (Figs. 3 and 7).

\section{Conclusions}

The Nyack floodplain is a shifting mosaic of habitat patches. The size and distribution of these patches change through time and across space in relation to the magnitude, duration, and recurrence intervals of flows. Variation in the magnitude and spatial extent of floodmediated disturbance creates habitats that are characterized by several stages of succession, resulting in dynamic and diverse terrestrial and aquatic habitats. We conclude that habitat change at Nyack is coherent with the pattern of the Pacific Decadal Oscillation (PDO): cooling phases of the PDO are characterized by frequent high flow events that restructure habitat whereas warming phases are associated with a decrease in the magnitude and duration of critical flows that promote vegetation regeneration and succession. This shifting habitat mosaic is a fundamental attribute of the structure and function of river ecosystems (Stanford et al. 2005), which is driven by alternating periods of flood disturbance and succession as mediated by regional climate patterns. Floodplains like Nyack with a diversity of habitats are important ecologically within regional landscapes (Stanford et al. 2005), but they are increasingly compromised by river impoundment, flow regulation, water abstraction, revetments, and other problems. Alterations to floodplains influence the trajectory of development of habitats and potentially the composition of species that utilize these landscapes.

\section{ACKNOWLedgments}

Funding for this study was provided by USA National Science Foundation grant number EAR-0120523 "Biocomplexity in the Environment-Dynamic Controls on Emergent Properties of River Floodplains." Mary Harner was supported by an NSF Integrative Graduate Education and Research Training Award (DGE 9972810) and an NSF Biocomplexity grant (DEB-0083422) at the University of New Mexico. We thank Susan Galatowitsch, Klement Tockner, Michelle Anderson, Dan Goodman, and the anonymous reviewers for comments and input on the manuscript.

\section{Literature Cited}

Arscott, D. B., K. Tockner, and J. V. Ward. 2002. Aquatic habitat dynamics along a braided Alpine river ecosystem (Tagliamento River, N.E. Italy). Ecosystems 5:802-814.

Bayley, P. B. 1995. Understanding large river-floodplain ecosystems. BioScience 45:153-158.

Bendix, J., and C. R. Hupp. 2000. Hydrological and geomorphological impacts on riparian plant communities. Hydrological Processes 14:2977-2990.

Bormann, F. H., and G. E. Likens. 1979. Pattern and process in a forested ecosystem. Springer-Verlag, New York, New York, USA.

Clark, J. S. 1988. Effect of climate change on fir regimes in northwestern Minnesota. Nature 334:233-235.

Clark, J. S. 1990. Patterns, causes, and theory of fire occurrence during the last $750 \mathrm{yr}$ in northwestern Minnesota. Ecological Monographs 60:135-169.

Costa, J. E., and J. E. O'Connor. 1995. Geomorphically effective floods. Pages 45-56 in J. E. Costa, A. J. Miller, K. W. Potter, and P. R. Wilcock, editors. Natural and anthropogenic influences in fluvial geomorphology. Geophysical Monograph 89. American Geophysical Union, Washington, D.C., USA.

Dettinger, M. D., S. D. Battisti, R. D. Garreaud, G. J. McCabe, Jr., and C. M. Blitz. 2000. Interhemispheric effects of interannual and decadal ENSO-like climate variations on the Americas. Pages 1-16 in V. Markgraf, editor. Present and past interhemispheric climate linkages in the Americas and their societal effects. Cambridge University Press, Cambridge, UK.

Doyle, M. W., E. H. Stanley, D. Strayer, R. Jacobson, and J. C. Schmidt. 2005. Effective discharge analysis of ecological processes in streams. Water Resources Research 41:W11411 [doi: 10.1029/2005WR004222].

Fisher, S. G., N. B. Grimm, E. Martí, R. M. Holmes, and J. B. Jones, Jr. 1998. Material spiraling in stream corridors: a telescoping ecosystem model. Ecosystems 1:19-34.

Graham, R. L., M. G. Turner, and V. H. Dale. 1990. How increasing $\mathrm{CO}_{2}$ and climate change affect forests. BioScience 40:575-587.

Hare, S. R., and N. J. Mantua. 2000. Empirical evidence for North Pacific regime shifts in 1977 and 1989. Progress in Oceanography 47:103-145.

Hare, S. R., N. J. Mantua, and R. C. Francis. 1999. Inverse production regimes: Alaskan and West Coast Salmon. Fisheries 24:6-14.

Harner, M. J., and J. A. Stanford. 2003. Differences in cottonwood growth between a losing and a gaining reach of an alluvial flood plain. Ecology 84:1453-1458.

Hauer, F. R., and M. S. Lorang. 2004. River regulation, decline of ecological resources, and potential for restoration in a semi-arid lands river in the western USA. Aquatic Sciences 66:1-14.

Hohensinner, S., G. Haidvogl, M. Jungwirth, S. Muhar, S. Preis, and S. Schmutz. 2005. Historical analysis of habitat turnover and age distributions as a reference for restoration of Austrian Danube floodplains. River Basin Management 3: 489-502. 
Hollowed, A. B., S. R. Hare, and W. S. Wooster. 1998. Pacificbasin climate variability and patterns of Northeast Pacific marine fish production. Pages 89-104 in G. Holloway, P. Muller, and D. Henderson, editors. Proceedings of the 10th "Aha Huliko," a Hawaiian Winter Workshop on Biotic Impacts of Extratropical Climate Variability in the Pacific. NOAA Award No. NA67RJ1054. SOEST Special Publication, Honolulu, Hawaii, USA.

Junk, W. J. 2005. Flood pulsing and the linkages between terrestrial, aquatic, and wetland systems. Internationalen Vereinigung für Theoretische und Angewandte Limnologie Verhandlungen 29:11-38.

Karrenberg, S., P. J. Edwards, and J. Kollman. 2002. The life history of Salicaceae living in the active zone of floodplains. Freshwater Biology 47:733-748.

Kollmann, J., M. Vieli, P. J. Edwards, K. Tockner, and J. V. Ward. 1999. Interactions between vegetation development and island formation in the alpine river Tagliamento. Applied Vegetation Science 2:25-36.

Latterell, J. J., J. S. Bechtold, T. C. O'Keefe, R. Van Pelt, and R. J. Naiman. 2006. Dynamic patch mosaics and channel movement in an unconfined river valley of the Olympic Mountains. Freshwater Biology 51:523-544.

Leopold, L. B. 1992. The sediment size that determines channel morphology. Pages 297-312 in P. Billi, editor. Dynamics of gravel-bed rivers. John Wiley, New York, New York, USA.

Lorang, M. S., and F. R. Hauer. 2003. Flow competence and streambed stability: an evaluation of technique and application. Journal of the North American Benthological Society 22:475-491.

Lytle, D. A., and D. M. Merrit. 2004. Hydrologic regimes and riparian forest: a structured population model for cottonwood. Ecology 85:2493-2503.

Mahoney, J. M., and S. B. Rood. 1998. Streamflow requirements for cottonwood seedling recruitment - an integrative model. Wetlands 18:634-645.

Mantua, N. J., and S. R. Hare. 2002. The Pacific decadal oscillation. Journal of Oceanography 58:35-44.

Merigliano, M. F. 1998. Cottonwood and willow demography on a young island, Salmon River, Idaho. Wetlands 18: 571-576.

Molles, M. C., and C. N. Dahm. 1990. A perspective on El Niño and La Niña: global implications for stream ecology. Journal of the North American Benthological Society 9:6876.

Mouw, J. E. B., and P. B. Alaback. 2003. Putting floodplain hyperdiversity in a regional context: an assessment of terrestrial-floodplain connectivity in a montane environment. Journal of Biogeography 30:87-103.

Overland, J. E., D. B. Percival, and H. O. Mojfeld. 2006. Regime shifts and red noise in the North Pacific. Deep-Sea Research I 53:582-588.

Parmesan, C., and G. Yohe. 2003. A globally coherent fingerprint of climate change impacts across natural systems. Nature 421:37-42.

Pederson, G. T., D. B. Fagre, S. T. Gray, and L. J. Graumlich. 2004. Decadal-scale climate drivers for glacial dynamics in Glacier National Park, Montana, USA. Geophysical Research Letters 31:L12203.
Poff, N. L., J. D. Allan, M. B. Bain, J. R. Karr, K. L. Prestegaard, B. D. Richter, R. E. Sparks, and J. C. Stromberg. 1997. The natural flow regime: a paradigm for river conservation and restoration. BioScience 47:769-784.

Power, M. E., R. J. Stout, C. E. Cushing, P. P. Harper, F. R. Hauer, W. J. Matthews, P. B. Moyle, B. Statzner, and I. R. Wais De Badgen. 1988. Biotic and abiotic controls in river and stream communities. Journal of the North American Benthological Society 7:456-479.

Resh, V. H., A. V. Brown, A. P. Covich, M. E. Gurtz, H. W. Li, G. W. Minshall, S. R. Reice, A. L. Sheldon, J. B. Wallace, and R. C. Wissmar. 1988. The role of disturbance in stream ecology. Journal of the North American Benthological Society 7:433-455.

Rood, S. B., A. R. Kalischuk, and J. M. Mahoney. 1998. Initial cottonwood seedling recruitment following the flood of the century of the Oldman River, Alberta, Canada. Wetlands 18: $557-570$.

Root, T. L., J. T. Price, K. R. Hall, S. H. Schneider, C. Rosenzweig, and J. A. Pounds. 2003. Fingerprints of global warming on wild animals and plants. Nature 421:57-60.

Scott, M. L., G. T. Auble, and J. M. Friedman. 1997. Flood dependency of cottonwood establishment along the Missouri River, Montana, USA. Ecological Applications 7:677-690.

Selkowitz, D. J., D. B. Fagre, and B. A. Reardon. 2002. Interannual variations in snowpack in the Crown of the Continent Ecosystem. Hydrological Processes 16:3651-3665. SPSS. 2003. SPSS for Windows. Version 12.0.2. SPSS, Chicago, Illinois, USA.

Stanford, J. A., M. S. Lorang, and F. R. Hauer. 2005. The shifting habitat mosaic of river ecosystems. Internationalen Vereinigung für Theoretische und Angewandte Limnologie Verhandlungen 29:123-136.

Stanford, J. A., J. V. Ward, W. J. Liss, C. A. Frissell, R. N. Williams, J. A. Lichatowich, and C. C. Coutant. 1996. A general protocol for restoration of regulated rivers. Regulated Rivers: Research and Management 12:391-413.

Stromberg, J. C. 1998. Functional equivalency of saltcedar (Tamarix chinensis) and Fremont cottonwood (Populus fremontii) along a free-flowing river. Wetlands 18:675-686.

Swetnam, T. W., and J. L. Betancourt. 1990. Fire-Southern Oscillation relations in the southwestern United States. Science 249:1017-1021.

Tockner, K., M. Florian, and J. V. Ward. 2000. An extension of the flood pulse concept. Hydrological Processes 14:2861-2883.

Tockner, K., and J. A. Stanford. 2002. Riverine flood plains: present state and future trends. Environmental Conservation 29:308-330.

van der Nat, D., K. Tockner, P. J. Edwards, J. V. Ward, and A. M. Gurnell. 2003. Habitat change in braided flood plains (Tagliamento, NE-Italy). Freshwater Biology 48:1799-1812.

Ward, J. V., K. Tockner, D. B. Arscott, and C. Claret. 2002. Riverine landscape diversity. Freshwater Biology 47:517-539.

Ward, J. V., K. Tockner, and F. Schiemer. 1999. Biodiversity of floodplain river ecosystems: ecotones and connectivity. Regulated Rivers: Research and Management 15:125-139.

Wolman, M. G., and J. P. Miller. 1960. Magnitude and frequency of forces in geomorphic processes. Journal of Geology 68:54-74. 